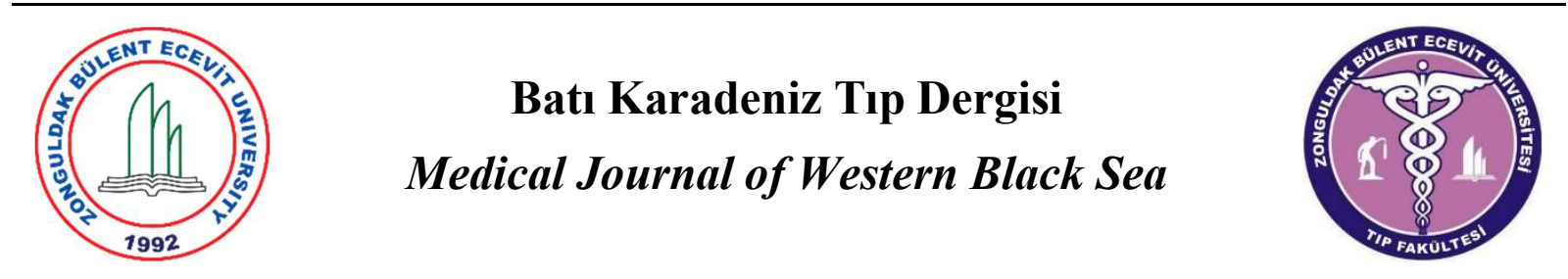

Araştırma Makalesi

Doi: $10.29058 /$ mjwbs.2019.3.2

\title{
Perkütan Nefrolitotomi Sonrası Oluşan Renal Arter Psödoanevrizmanın Tedavisinde Selektif Mikrokateter Koil Embolizasyonunun Değerlendirilmesi
}

\section{Bekir Turgut ${ }^{\mathrm{a}}$, Mahmud Zahid Ünlü ${ }^{\mathrm{b}}$}

${ }^{a}$ Konya Eğitim ve Araştırma Hastanesi, Sağlık Bilimleri Üniversitesi, Radyoloji Anabilim Dalı, Konya, Türkiye.

${ }^{b}$ Konya Eğitim ve Araştırma Hastanesi, Sağlık Bilimleri Üniversitesi, Üroloji AnabilimDalı, Konya, Türkiye.

ORCID : Bekir Turgut 000000018276 9996, Mahmud Zahid Ünlü 0000000278503746

\begin{tabular}{|c|c|}
\hline $\begin{array}{l}\text { M A K A L E } \\
\text { B I L G İ S I }\end{array}$ & Ö Z \\
\hline $\begin{array}{l}\text { Gönderilme Tarihi: } \\
\text { 30.09.2019 } \\
\text { Revizyon: } \\
\text { 18.12.2019 } \\
\text { Kabul: } \\
\text { 20.12.2019 } \\
\text { Sorumlu Yazar: } \\
\text { Bekir Turgut } \\
\text { drbekirturgut@gmail.com } \\
\text { Anahtar Kelimeler: } \\
\text { Renal Arter Psödoanevrizma; } \\
\text { Selektif Mikrokateter Koil } \\
\text { Embolizasyonu; Hematüri; } \\
\text { Perkütan Nefrolitotomi }\end{array}$ & $\begin{array}{l}\text { Amaç: Distal renal arter psödoanevrizma tedavisinde kullanılan } \\
\text { selektif mikrokateter koil embolizasyonunun teknik başarısını ve } \\
\text { sonrasında gelişen parankim kaybının böbrek fonksiyonları üzerine } \\
\text { etkisini araştırmayı amaçladık. } \\
\text { Gereç ve Yöntemler: Perkütan nefrolitotomi operasyonu olan } 516 \\
\text { hastanın kayıtlı dosya bilgileri ve görüntüleme kayıtları tarandı. } \\
\text { Psödoanevrizma etyolojili sekiz(\%1.55) hasta çalışmaya dahil edildi. } \\
\text { Hastaların demografik özellikleri ve klinik takip durumları kayıt } \\
\text { edildi. Psödoanevrizma boyutu, lokalizasyonu ve embolizasyon } \\
\text { sonrası parankim kaybı transkateter anjiyografi görüntüleri ile } \\
\text { değerlendirildi. } \\
\text { sonrasında elde edilen anjiyografi görüntüleri karşılaştırılarak } \\
\text { değerlendirildi. Preoperatif ve postoperatif serum üre, hemoglobin } \\
\text { ve GFR değerleri kaydedildi. Bu veriler istatiksel olarak } \\
\text { karşılaştırıldı ve parankimal kaybın böbrek fonksiyonuna etkisi } \\
\text { değerlendirildi. Tedavide teknik başarı embolizasyon sonrası } \\
\text { anevrizmanın kontrast madde ile dolmaması ve klinik başarı } \\
\text { hematüri semptomunun düzelmesi olarak kabul edildi. } \\
\text { Bulgular: Sekiz psödoanevrizmanın tamamı distal renal arterden } \\
\text { (interlobar/interlobuler) kaynaklanmıştır. Ortalama boyutu } 23.25(9- \\
\text { 38) mm idi. Embolizasyon sonrası takipte ortalama } 2.8 \text { günde } \\
\text { makroskopik hematüri bulgusu kayboldu. Selektif mikrokateter koil } \\
\text { embolizasyonu teknik ve klinik başarı oranımız \%100 oldu. Beş } \\
\text { hastada <\% } \% \text {, iki hastada \%5-10, bir hastada \%25-50 oranında } \\
\text { parankim kaybı izlendi. Plazma hemoglobin, üre ve GRF'da } \\
\text { embolizasyon öncesi ve sonrası arasında istatistik olarak anlamlı } \\
\text { farklılık saptanmadı(sırasıyla p=0.814, 0.076, } 0.263) \text {. } \\
\text { Sonuç: Selektif mikrokateter koil embolizasyonu perkütan } \\
\text { nefrolitotomi sonrası oluşan renal psödoanevrizma tedavisi için } \\
\text { güvenli ve etkin bir yöntemdir. }\end{array}$ \\
\hline
\end{tabular}




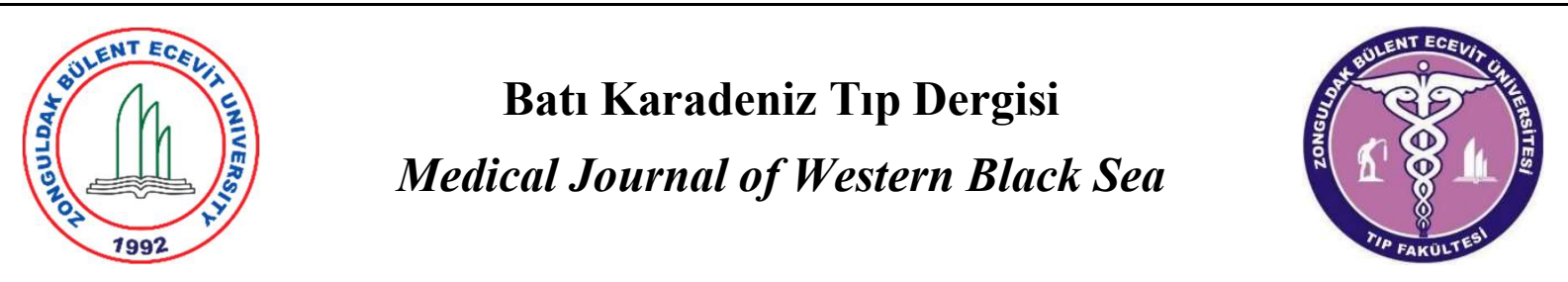

Research Article

Doi: 10.29058/mjwbs.2019.3.2

\title{
Evaluation of Selective Microcatheter Coil Embolization in the Treatment of Renal Artery Pseudoaneurysm Following Percutaneous Nephrolithotomy
}

\author{
Bekir Turgut ${ }^{a}$, Mahmud Zahid Ünlü ${ }^{b}$ \\ ${ }^{a}$ Department of Radiology, University of Health Sciences, Konya Training and Research Hospital, \\ Konya/Turkey \\ ${ }^{b}$ Department of Urology, University of Health Sciences, Konya Training and Research Hospital, Konya/Turkey
}

\begin{tabular}{l} 
A R T I C L E \\
I N F O R M A T I O N \\
\hline Date of Submission \\
30.09.2019 \\
Revision: \\
18.12.2019 \\
Accepted: \\
20.12.2019 \\
Correspondence Author: \\
Bekir Turgut \\
drbekirturgut@gmail.com \\
\hline Key Words: \\
Renal Artery Pseudoaneurysm; \\
Selective Microcatheter Coil \\
Embolization; Hematuria; \\
Percutaneous Nephrolithotomy
\end{tabular}

\begin{abstract}
A B S T R A C T
Aim: To investigate the technical success of selective microcatheter coil embolization for the treatment of distal renal artery pseudoaneurysm and to determine the effect of parenchymal loss on renal function.

Material and Methods: In this study, the medical files and imaging records of 516 patients who underwent percutaneous nephrolithotomy at our clinic from May 2015 to December 2018 were retrospectively reviewed. Eight $(1.55 \%)$ patients with renal artery pseudoaneurysms were included in the study. Preoperative and postoperative serum urea, hemoglobin and GFR values were recorded. These data were compared statistically and the effect of parenchymal loss on renal function was evaluated. The technical success of the treatment was accepted as the absence of contrast filling after embolization and clinical success was accepted as the absence of hematuria.
\end{abstract}

Results: Eight patients with renal artery pseudoaneurysm were included in the study. All of the aneurysms originated from the distal renal artery (interlobar / interlobuler). The mean size of the aneurysms was 23.25 (9-38) $\mathrm{mm}$. The technical and clinical success rates of microcatheter embolization were 100\%. Macroscopic hematuria disappeared at a mean of 2.8 days after treatment. Five patients had $<5 \%$ parenchymal loss, two had $5-10 \%$ and one patient had $25-50 \%$. There was no statistically significant difference between plasma hemoglobin, urea and GRF before and after embolization ( $p=0.814,0.076,0.263$, respectively).

Conclusion: Selective microcatheter coil embolization is a safe and effective method for the treatment of renal artery pseudoaneurysms after percutaneous nephrolithotomy. 


\section{Introduction}

Percutaneous nephrolithotomy (PCNL) is the most preferred method in the treatment of patients with kidney stones who did not respond to extracorporeal shock wave lithotripsy (ESWL) and also in those with kidney stones larger than $2 \mathrm{~cm}$ which may cause pelvicalyceal dilatation (1). Signs of hematuria after PCNL may occur between 1-20 days (2-4). Although computed tomography (CT) is recommended for diagnosis, direct selective angiography (DSA) is the gold standard diagnostic method (5). If hematuria cannot be controlled by conservative treatment, DSA may be the first choice as both a diagnostic and therapeutic method (6). Vascular lesions that cause hematuria may occur after renal interventions and are often seen in the renal arteries $(7,8)$

Pseudoaneurysms (PAs) may be observed in the renal artery and could be associated with macroscopic hematuria after PCNL. Iatrogenic renal artery lesions such as PA are rare but have a high mortality. Catheter angiography is the gold standard for both diagnosis and treatment (9). The major symptom is macroscopic hematuria which causes blood loss and may lead to hemorrhagic shock without treatment in severe cases (9-11). The success of minimally invasive selective transcatheter embolization has been shown to be quite high in the treatment of these cases. Furthermore, only minimal complications are reported with this procedure (12, 13).

In this study we aimed to investigate the technical success of selective microcatheter coil embolization for the treatment of distal renal artery pseudoaneurysms and to determine the effects of parenchyma loss on the renal function of patients who underwent this procedure.

\section{Material and Methods}

\section{Study Group}

A total of 516 patients who underwent percutaneous nephrolithotomy at the between May 2015 and December 2018 were retrospectively evaluated for inclusion into this study. Catheter angiography was performed on 16 patients with macroscopic hematuria that had not improved with conservative treatment. Five patients had no vascular problems such as renal PA, extravasation or arteriovenous fistula. Three patients had arteriovenous fistula in the renal artery interlobar segment. Eight patients had PA distal to the renal artery. These eight patients with PA were treated with endovascular embolization.

This work was approved by the local ethics committee (protocol no: 2019/0021). Treatment methods were performed according to approved guidelines. Verbal consent was obtained from all patients in the study for the use of medical file data and recorded imaging findings. Additionally, informed consent was obtained from patients included in the study prior to catheter angiography.

\section{Measurements}

The demographic characteristics and clinical follow-up of the patients were recorded. The size, number and location of PAs were evaluated by angiography images. To evaluate parenchymal loss, angiography images obtained before and after embolization were compared (Figure 1a, 1b). Areas with contrast enhancement before embolization and areas with no contrast enhancement after embolization were recorded and areas without contrast enhancement were compared to the area of the parenchyma with contrast enhancement. This calculation provided a semi-quantitative result. The degree of parenchymal loss was categorized in four groups according to the results: $<5 \%, 5-10 \%, 10$ $25 \%$ and $25-50 \%$.

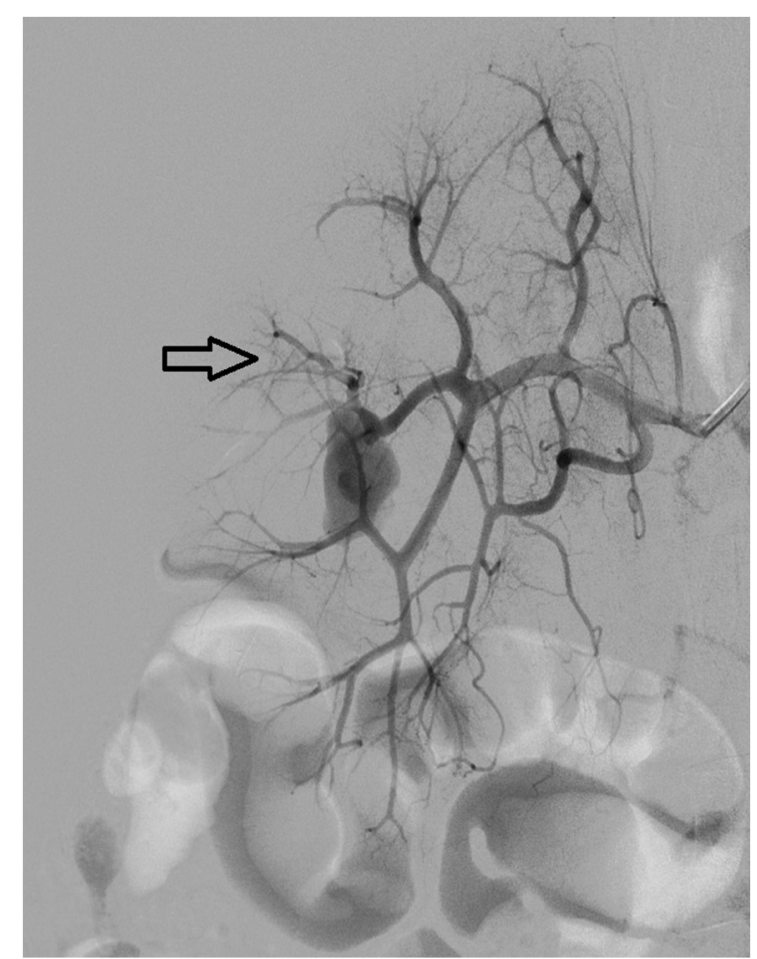

Figure 1a. A female patient with hematuria for 15 days after percutaneous nephrolithotomy had a 26x17 mm pseudoaneurysm in the middle segment of the right kidney. 


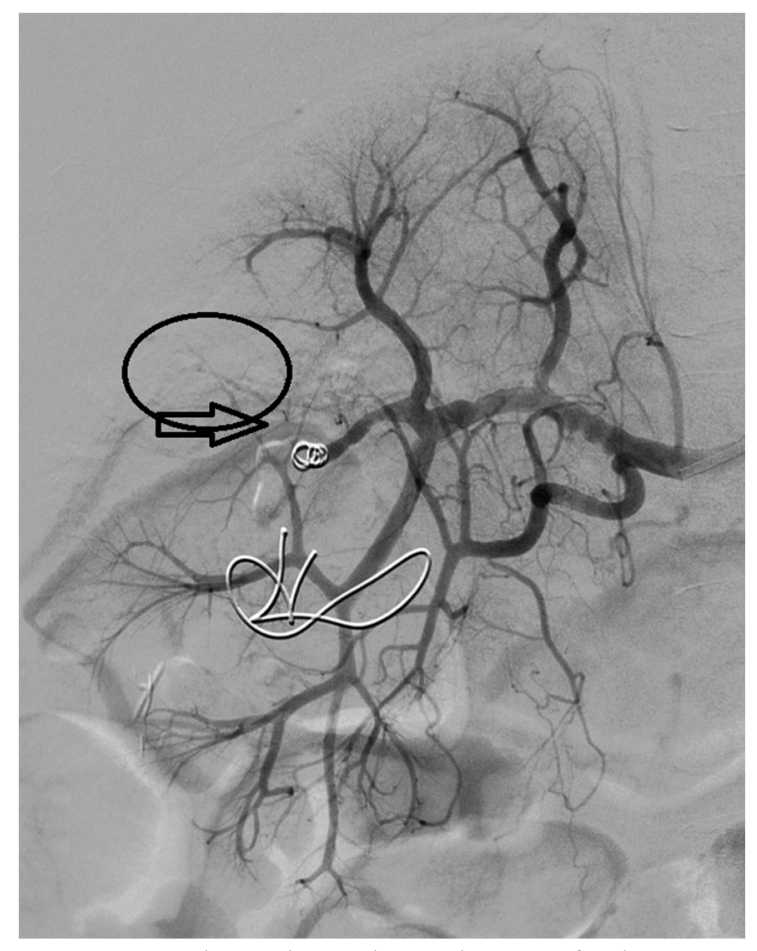

Figure 1b. The patient who underwent feeder artery coil embolization had a parenchymal loss of 5-10\% (oval area) after embolization. There was no contrast enhancement in the distal of the embolized artery (arrow).

Preoperative and postoperative blood plasma urea, hemoglobin and GFR levels were recorded. Preoperative parameters were evaluated with venous blood taken one day before embolization. Postoperative parameters were evaluated with venous blood taken two days after embolization.

The technical success of the treatment was accepted as the absence of PA contrast filling after embolization and clinical success was accepted as the absence of hematuria.

\section{Embolization Procedure}

Access was obtained with a transfemoral introducer $5 \mathrm{~F}$ sheath after local anesthesia. Renal artery angiography was performed. 5F Cobra or Simon 2 catheters (Boston Scientific, USA) were used for selective catheterization. Segmental and interlobar arteries causing bleeding were detected. Superselective catheterization was performed on these arteries using the microcatheter system (Direxion Microcatheter; Boston Scientific, USA). The PA feeder artery and/or the PA were embolized using a coil. Embolization was completed when the contrasting (indicating blood flow) of the lesion and the feeding artery had ceased in control angiography images (Figure 2a, 2b, 2c). We used pushable coils
(VORTX-18 Diamond Shape coils, Boston Scientific, USA) in four patients, and controlled release coils in the remaining four patients (GDC coils, Boston Scientific, USA).

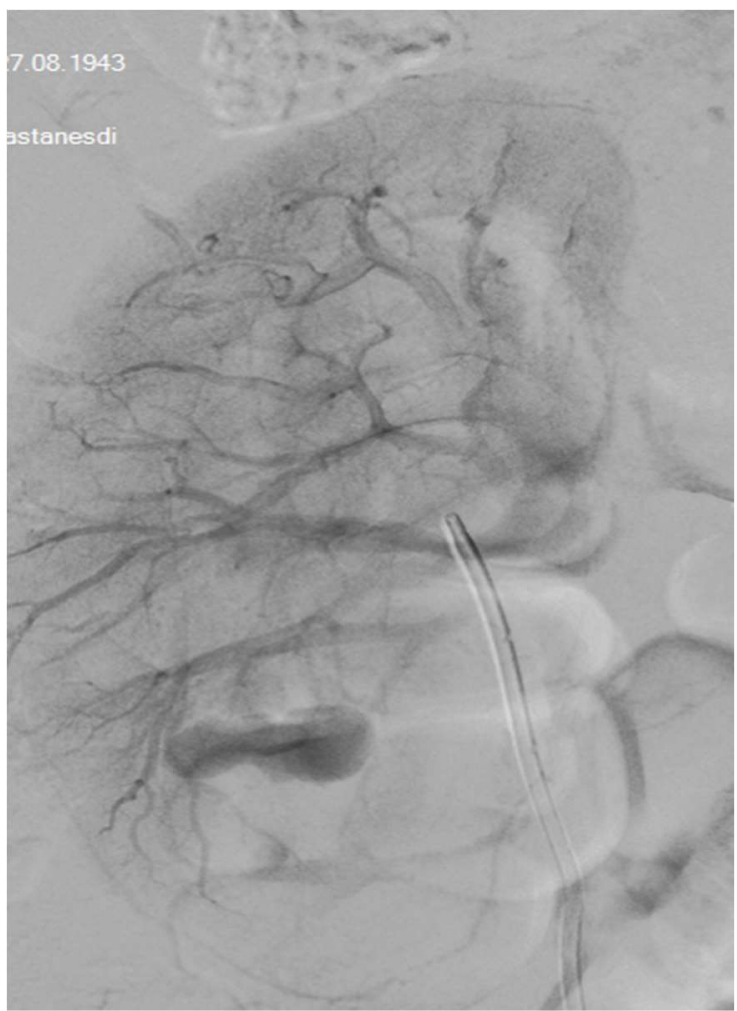

Figure 2a. On the 7th day after percutaneous nephrolithotomy, the patient has hematuria and right renal artery angiography is performed. There was a 26x11 mm pseudoaneurysm in the interlobar artery of the right kidney.

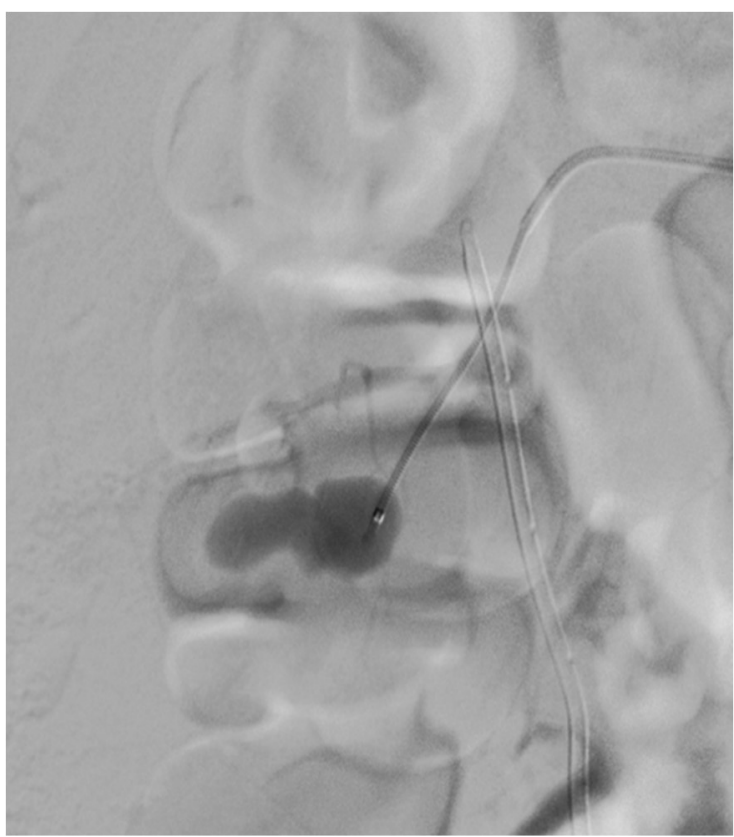

Figure 2b. Pseudoaneurysm with microcatheter was selectively catheterized. 


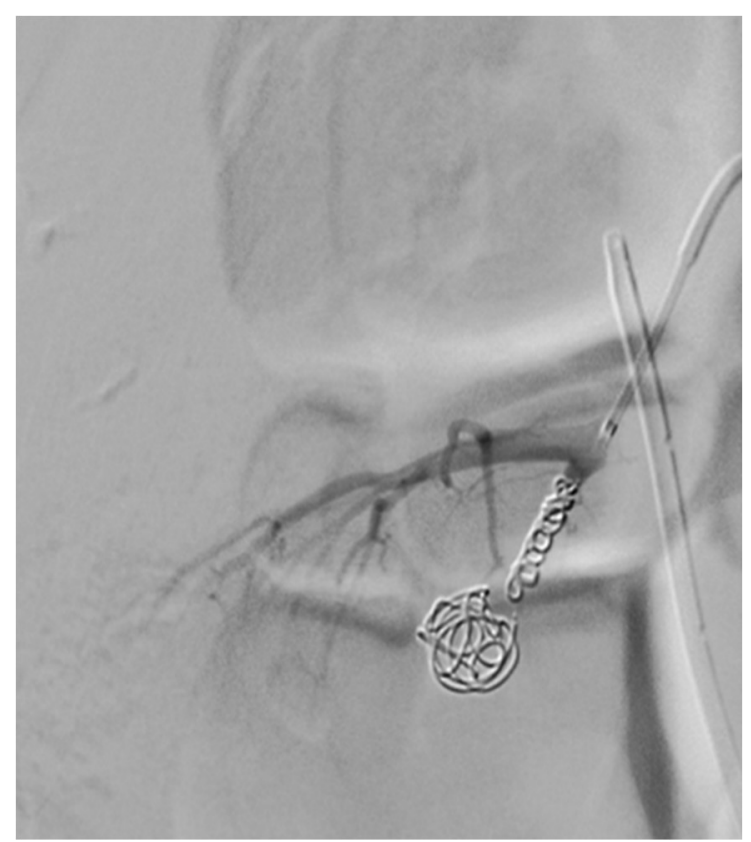

Figure 2c. The proximal half of the pseudoaneurysm and the feeder artery were embolized with coils. The renal parenchymal loss rate was $<5 \%$.

\section{Statistical Analysis}

All analyses were performed on SPSS v20. Normally-distributed variables were presented as mean \pm standard deviation (mean $\pm \mathrm{SD}$ ). For all other numerical variables, values were given as mean $\pm \mathrm{SD}$ with medians and minimum-maximum (min-max) values when required.
Comparison of pre- and post-operative values were performed with the Paired t-test and the Wilcoxon signed-rank test depending on normality of distribution. $\mathrm{p} \leq 0.05$ values were accepted as statistically significant.

\section{Results}

We included 8 patients into our study, mean age was 56 (37-80) years. All patients underwent coil embolization. The lesion localization was mostly in the lower pole of the right kidney. All lesions were localized in the distal renal artery (interlobar / interlobular). Five patients had $<5 \%$ parenchyma loss, two patients had 5-10\% loss while one patient was found to have a parenchyma loss of $25-50 \%$. The mean follow-up period was 9 days (Table 1).

All patients had macroscopic hematuria, four had flank pain, perirenal hematoma was not present in any patient. Macroscopic hematuria disappeared at a mean of 2.8 (1-6) days after the treatment. The technical and clinical success rate of the treatment was $100 \%$. After the treatment, the patients were followed up for a mean of 6 (4-9) days. No complications were found in any of the patients and none required a second embolization.

There was no statistically significant difference between plasma hemoglobin, urea and GFR before and after embolization $(\mathrm{p}=0.814,0.076,0.263$, respectively) (Table 2 ).

Table 1. Baseline characteristic of patients

\begin{tabular}{|c|c|c|c|c|c|}
\hline & $\begin{array}{c}\text { Age/ } \\
\text { Gender }\end{array}$ & $\begin{array}{c}\text { PA } \\
\text { Localization } \\
\text { (kidney) }\end{array}$ & $\begin{array}{l}\text { PA size (mm) } \\
\text { Length / width }\end{array}$ & $\begin{array}{l}\text { Follow-up } \\
\text { period(days) }\end{array}$ & $\begin{array}{c}\text { Parenchyma loss } \\
\text { rate }(\%)\end{array}$ \\
\hline Patient 1 & $42 / \mathrm{M}$ & left & $37 / 17$ & 5 & $<5$ \\
\hline Patient 2 & $51 / \mathrm{F}$ & right & $26 / 17$ & 15 & $5-10$ \\
\hline Patient 3 & $61 / F$ & right & $9 / 4$ & 10 & $<5$ \\
\hline Patient 4 & $44 / \mathrm{M}$ & left & $38 / 16$ & 5 & $25-50$ \\
\hline Patient 5 & $37 / \mathrm{M}$ & right & $17 / 8$ & 16 & $5-10$ \\
\hline Patient 6 & $59 / \mathrm{F}$ & right & $14 / 6$ & 6 & $<5$ \\
\hline Patient 7 & $75 / \mathrm{M}$ & right & $26 / 11$ & 7 & $<5$ \\
\hline Patient 8 & $80 / \mathrm{F}$ & left & $19 / 11$ & 8 & $<5$ \\
\hline
\end{tabular}

PCNL; percutaneous nephrolithotomy, PA; pseudoaneurysm, M; male, F; Female. 
Table 2 Blood plasma values before and after embolization in patients.

\begin{tabular}{|c|c|c|c|c|c|c|}
\hline & $\mathbf{n}$ & Min & Max & Mean & Std. Deviation & p value \\
\hline Pre-hemoglobin(g/dl) & 8 & 7.50 & 12.00 & 9.50 & 1.39 & \multirow{2}{*}{$0.814^{\mathrm{a}}$} \\
\hline Post-hemoglobin(g/dl) & 8 & 7.70 & 11.20 & 9.36 & 1.29 & \\
\hline Pre-urea(mmol/L) & 8 & 24.00 & 106.00 & 45.50 & 26.67 & \multirow{2}{*}{$0.076^{\mathrm{a}}$} \\
\hline Post-urea(mmol/L) & 8 & 21.00 & 103.00 & 41.75 & 27.01 & \\
\hline Pre-eGFR(ml/min) & 8 & 16.00 & 108.00 & 76.87 & 30.34 & \multirow{2}{*}{$0.263^{\mathrm{a}}$} \\
\hline Post-eGFR(ml/min) & 8 & 24.00 & 105.00 & 73.25 & 25.68 & \\
\hline
\end{tabular}

pre-op: before operation; postop: post-operation; a: Paired t-test

\section{Discussion}

In this study we evaluated the technical and clinical success of selective microcatheter coil embolization used in the treatment of 8 patients with distal renal artery PA. We also evaluated the effect of postoperative parenchymal loss on the renal function of patients. After the treatment, the technical and clinical success rate was $100 \%$. The rate of parenchymal loss after microcatheter coil embolization was deemed to be acceptable. None of the patients had significant deterioration of renal function after embolization.

The etiology of PA is believed to be the direct result of injury to a segmental branch of the renal artery, leading to a collection of blood in the surrounding tissue that freely communicates with the intravascular space. The vascular injury is initially controlled by a combination of decreased blood flow, coagulation and the tamponading effect of the surrounding tissue, which initially prevent hemorrhage.

As these temporary measures begin to degrade and the patient becomes more active, the blood flow to the vessel increases and a collection of blood from the renal artery may begin to accumulate in the extravascular space, facilitating the formation of the pseudoaneurysm. Blood can then extend and leak into the collecting system, thus causing gross hematuria (14). Almost all patients with PA have macroscopic hematuria and the majority report flank pain $(13,15)$. Similarly, macroscopic hematuria was present in all patients in our study. However, only $50 \%$ of our patients had flank pain.

Complications after percutaneous renal interventions usually occur within three weeks. The frequency of macroscopic hematuria after percutaneous renal intervention is $6 \%(16)$. The most common cause is PA (17-20). In a study by Richstone et al., it was reported that macroscopic hematuria, which required selective endovascular embolization, developed in 57 of 4695 (1.2\%) patients who underwent percutaneous kidney intervention. The intervention leading to hematuria in 44 of these 57 patients was reported to be PCNL (21). Similarly, Srivastava et al. found that, among the 1854 PCNL procedures included in their study, 24 had resulted in macroscopic hematuria which necessitated embolization (2). Similarly, in our study, $8(1.55 \%)$ of the patients who underwent PCNL developed PA and had macroscopic hematuria.

Contrast-enhanced CT may be preferred in the diagnosis of PA as it is a non-invasive procedure. However, percutaneous angiography is very often the first choice (and gold standard) despite the high risk for morbidity and mortality (22). In our study, due to the strong suspicion of PA, we performed transfemoral catheter angiography as a method of direct diagnosis and treatment. We did not utilize intravenous contrast-enhanced CT before catheter angiography in any of our patients. Thus, additional costs with CT imaging and the use of additional contrast materials were avoided. In addition, the patients did not receive any additional radiation.

The embolization can be performed using a variety of embolic agents: autologous blood clot, detachable balloons, coils, particles and N-butyl-2cyanoacrylate. However, coil embolization is very effective for complete closure of the target vessels. Selective embolization of PA is achieved by occlusion of feeder arteries using micro-coils (23). In our study, we applied microcatheter coil 
embolization to all patients. The technical and clinical success rate of the procedure was $100 \%$. After the treatment, no complications developed and there was no requirement for secondary embolization. These success rates are similar to reports from the literature $(14,23-25)$.

Lack of enhancement in angiography indicates loss of renal parenchyma. A high rate of parenchymal loss is a risk factor for impaired renal function after embolization. Microcatheters are used for superselective catheterization of the distal branches (segmental / interlobar / interlobular) so that loss of parenchyma is minimized (6). Furthermore, with microcatheter embolization, isolation of the vascular lesion is easily achieved while renal vascularization is unharmed. Rennert et al. used Onyx as an embolizing agent in their study. They described moderate parenchymal loss in four patients. They reported three patients had wedgeshaped focal parenchymal loss and one patient had $30-40 \%$ parenchymal loss. Additionally, they reported one patient had parenchymal loss in the upper pole which was a necessary result of the treatment (26). Kervancioğlu et al. evaluated the treatment of vascular complications after PCNL with transcatheter coil embolization and reported parenchymal loss in all patients. They found that twelve patients had parenchymal loss of $<10 \%$ and four patients had parenchymal loss between 10-20\% (6). Smilarly, in our study, five patients had a parenchyma loss of $<5 \%$, two patients $5-10 \%$ and one patient $25-50 \%$. The clinical significance of renal parenchymal loss is determined by renal dysfunction after embolization. In our study, there was no statistically significant difference between hemoglobin, urea and GFR before and after embolization. In the study by Srivastava et al., serum creatinine levels were also similar before and after embolization (2).

Therefore, considering the results of our study and previous research, we believe that selective microcatheter coil embolization may be the first line treatment of PA after PCNL, due to its high technical success and safety.

There are various limitations in our study. First of all, the retrospective single center design may be a cause of bias as well as limiting the generalization of results. The second most important limitation is the relatively small study population; however, PA development following PCNL is quite rare and studies until know have been comprised of similarly small patient numbers. It is known that there is a compensatory increase in the blood flow to the kidneys after renal surgery. Since we cannot quantify this situation quantitatively, our measurement of renal function loss after embolization may be limited.

Pseudoaneurysm of the distal renal artery is a rare complication after PCNL but it is an important complication as it can cause severe macroscopic hematuria which could lead to severe renal problems. Catheter angiography can be performed for both the diagnosis and treatment of PA without the need for confirmation with contrast-enhanced CT, especially in cases with strong suspicion. Thus, we believe selective microcatheter coil embolization is a safe and effective treatment method with minimal parenchymal loss and high technical / clinical success rate in the treatment of PA after PCNL procedures.

\section{References}

1. Dede O, Kayan D, Sezgin T, Aydoğmuş Y. Our experience of the first 70 percutaneous nephrolithotomy at Bitlis State Hospital; a retrospective analysis. The New Journal of Urology 2015; 10 (2): 06-11

2. Srivastava A, Singh KJ, Suri A, Dubey D, Kumar A, Kapoor R, et al. Vascular complications after percutaneous nephrolithotomy: are there any predictive factors? Urology. 2005;66(1):38-40.

3. Soyer P, Desgrippes A, Vallee J-N, Rymer R. Intrarenal pseudoaneurysm after percutaneous nephrostolithotomy: endovascular treatment with $\mathrm{N}$ butyl-2-cyanoacrylate. European radiology. 2000;10(8):1358.

4. Falahatkar S, Hemmati H, Mokhtari G, Assadollahzadeh A, Allahkhah A. Intrarenal Pseuodoaneurysm after percutaneous nephrolithotomy: A rare and important complication of minimally invasive surgery. 2011;4:2.

5. Chandradev S, Ateesh S. Endovascular and percutaneous management of the pseudoaneurysms. Open Journal of Radiology. 2014;4(03):241.

6. Kervancioglu S, Gelebek Yilmaz F, Erturhan S. Endovascular management of vascular complications after percutaneous nephrolithotomy. Vasa. 2014;43(6):459-464.

7. Tan T, Teh H, Pua U, Ho S. Endovascular management of iatrogenic renal vascular injuries complicating percutaneous nephrolithotripsy: Role 
of renal angiography and superselective coil embolisation. J HK Coll Radiol. 2008;11:103-107.

8. Abath C, Andrade G, Cavalcanti D, Brito N, Marques R. Complex renal artery aneurysms: liquids or coils? Techniques in vascular and interventional radiology. 2007;10(4):299-307.

9. Hyams ES, Pierorazio P, Proteek O, Sukumar S, Wagner AA, Mechaber JL, et al. Iatrogenic vascular lesions after minimally invasive partial nephrectomy: a multi-institutional study of clinical and renal functional outcomes. Urology. 2011;78(4):820-826.

10. Inci K, Cil B, Yazici S, Peynircioglu B, Tan B, Şahin A, et al. Renal artery pseudoaneurysm: complication of minimally invasive kidney surgery. Journal of endourology. 2010;24(1):149-154.

11. Singh D, Gill IS. Renal artery pseudoaneurysm following laparoscopic partial nephrectomy. The Journal of urology. 2005;174(6):2256-2259.

12. Gahan JC, Gaitonde M, Wadskier L, Cadeddu JA, Trimmer C. Renal function outcomes following selective angioembolization for iatrogenic vascular lesions after partial nephrectomy. Journal of endourology. 2013;27(12):1516-1519.

13. Ghoneim TP, Thornton RH, Solomon SB, Adamy A, Favaretto RL, Russo P. Selective arterial embolization for pseudoaneurysms and arteriovenous fistula of renal artery branches following partial nephrectomy. The Journal of urology. 2011;185(6):2061-2065.

14. Shapiro EY, Hakimi AA, Hyams ES, Cynamon J, Stifelman M, Ghavamian R. Renal artery pseudoaneurysm following laparoscopic partial nephrectomy. Urology. 2009;74(4):819-823.

15. Kobayashi K, Censullo ML, Rossman LL, Kyriakides PN, Kahan BD, Cohen AM. Interventional radiologic management of renal transplant dysfunction: indications, limitations, and technical considerations. Radiographics. 2007;27(4):1109-1130.

16. Ramani AP, Desai MM, Steinberg AP, Ng CS, Abreu SC, Kaouk JH, et al. Complications of laparoscopic partial nephrectomy in 200 cases. The Journal of urology. 2005;173(1):42-47.
17. Albani JM, Novick AC. Renal artery pseudoaneurysm after partial nephrectomy: three case reports and a literature review. Urology. 2003;62(2):227-231.

18. Chatziioannou A, Mourikis D, Awad M, Konstantinedes P, Panourgias E, Vlachos L. Embolization of a segmental renal artery pseudoaneurysm after partial nephrectomy in a solitary kidney. Urologia internationalis. 2000;64(4):223-225.

19. Heye S, Maleux G, Van Poppel H, Oyen R, Wilms G. Hemorrhagic complications after nephronsparing surgery: angiographic diagnosis and management by transcatheter embolization. American Journal of Roentgenology. 2005;184(5):1661-1664.

20. Parsons JK, Schoenberg MP. Renal artery pseudoaneurysm occurring after partial nephrectomy. Urology. 2001;58(1):105.

21. Richstone L, Fossett LK, Okeke Z, Ost MC, Rastinehad AR, Lobko I, et al. 1688: Hemorrhage Following Percutaneous Renal Surgery: Characterization of Angiographic Findings. The Journal of Urology. 2007;177(4):560.

22. Helck A, Hoffmann R, Sommer W, Notohamiprodjo M, Albyaa $\mathrm{H}$, Reiser $\mathrm{M}$, et al. Diagnosis, therapy monitoring and follow up of renal artery pseudoaneurysm with contrast-enhanced ultrasound in three cases. Clinical hemorheology and microcirculation. 2010;46(2-3):127-37.

23. Tinto H, Di Primio M, Tselikas L, Rico AP, Pellerin O, Pagny J-Y, et al. Selective arterial embolization of life-threatening renal hemorrhage in four patients after partial nephrectomy. Diagnostic and interventional imaging. 2014;95(6):601-9.

24. Netsch C, Brüning R, Bach T, Gross A. Management of renal artery pseudoaneurysm after partial nephrectomy. World journal of urology. 2010;28(4):519-24.

25. Ierardi AM, Floridi C, Fontana F, Duka E, Pinto A, Petrillo M, et al. Transcatheter embolisation of iatrogenic renal vascular injuries. La radiologia medica. 2014;119(4):261-8.

26. Rennert J, Herold T, Schreyer A, Banas B, Jung E, Feuerbach S, et al., editors. Evaluation of a liquid embolization agent (Onyx) for transcatheter embolization for renal vascular lesions. RöFo- 
Fortschritte auf dem Gebiet der Röntgenstrahlen und der bildgebenden Verfahren; 2009: (C) Georg Thieme Verlag KG Stuttgart· New York. 